\title{
Application of ultrasound in endodontics
}

\author{
Lyudmila Y. Orekhova', Tat'yana V. Porkhun², Veronika Y. Vashneva ${ }^{2}$, Ekaterina A. Rubezhova ${ }^{3}$ \\ ${ }^{1} \mathrm{MD}$, PhD, DMSci, Professor, Pavlov First State Medical University, Saint-Petersburg, Russia \\ ${ }^{2} \mathrm{MD}$, PhD, Associate professor, Pavlov First State Medical University, Saint-Petersburg, Russia \\ ${ }^{3}$ Pavlov First State Medical University, Saint-Petersburg, Russia
}

\begin{abstract}
Summary. The aim of this study is to evaluate the efficiency of ultrasound in endodontic practice in various clinical cases. Objects and methods. Extracted teeth, divided into 2 experimental groups, were used to assess the degree of the tooth cavity cleaning. In the first group, the tooth cavity was treated mechanically and medically without ultrasound use. In the second group, the tooth cavity was treated mechanically and medically with ultrasound use. Ultrasound treatment was found to improve significantly the level of tooth cavity cleaning at the preparatory stage for endodontic treatment.

Extracted teeth, divided into 3 experimental groups were used in our study to demonstrate the efficiency of passive ultrasonic irrigation.

Results and discussion. The results of scanning electron microscopy of extracted teeth slices which show the level of purification of the root canal previously treated mechanically and medically are attached to the article. Our research leads to the conclusion that the activation of the irrigation solution with sound or ultrasound leads to significant increase in quality of root canal cleaning.

The article presents 3 clinical cases of ultrasound application in procedure of extraction a silver post, a fiberglass post and a fragment of the canal filling instrument from the root canal. The research has found that use of ultrasound in modern endodontic practice facilitates the extraction of intracanal posts and instrument fragments, with duration of intervention being reduced and the possibility of saving the tooth in complicated clinical cases being increased.

Conclusion. The results of the research lead to the conclusion that ultrasound should be used almost at every stage of endodontic treatment.
\end{abstract}

Keywords: ultrasound, endodontics, root canal, passive ultrasonic irrigation, post removal, broken instruments removal

\section{INTRODUCTION}

Modern endodontic treatment is impossible without use of ultrasound [9]. The use of ultrasonic tips makes manipulations more qualitative and predictable $[1,8,25]$.

The indications for use of ultrasound in endodontics are: tooth cavity preparation for further endodontic treatment; search for root canals; retreatment of root canals, sealed with cement, resorcin-formalin or gutta-percha; removal of fiberglass, silver, or anchor posts and parts of broken instruments from the root canal $[8,11]$; activation of irrigation solutions (passive ultrasonic irrigation); removal of denticles, petrifications of the root canals $[10,12,24]$. Thus, ultrasound is used almost at every stage of endodontic treatment.

\section{THE AIM OF THE PRESENT RESEARCH}

The aim of the study is to evaluate the efficiency of ultrasound in endodontic practice in various clinical cases.
The following tasks were set to achieve this goal: to prove the efficiency of using ultrasound for qualitative preparation of the tooth cavity before root canals preparation; to compare the quality of root canal cleaning after activation of the irrigation solution with sound and ultrasound; to show the advantages of ultrasound use during removal of posts and parts of broken instruments from the root canal.

\section{OBJECTS AND METHODS}

Ultrasound should be used to prepare the tooth cavity for further endodontic treatment.

Ultrasonic treatment provides better cleaning of the walls and bottom of the tooth cavity, removal of calcifications, "dentin cornices", and enables locating entrances to additional root canals $[8,11]$.

The technique of the tooth cavity ultrasonic treatment consists of careful removal 


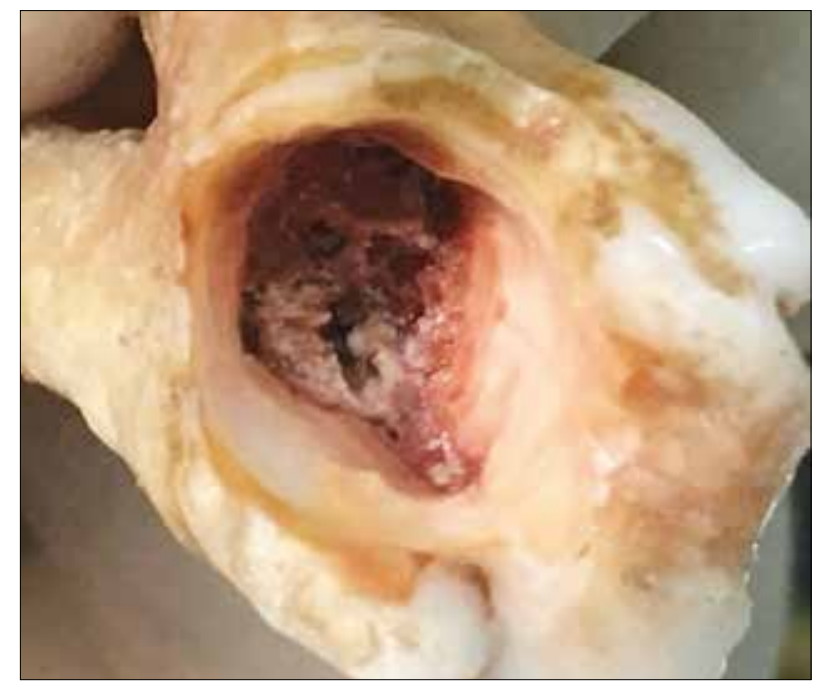

Fig. 1. The 16th tooth cavity before ultrasound treatment

of the bright white near-pulp dentin with an endodontic tip in the direction of the root canal. The use of ultrasound at this stage reduces the risk of perforations, especially in the area of root furcation.

The complementary use of ultrasound improves significantly the quality of preparation of the tooth cavity (mechanical, medicated) before endodontic treatment.

10 extracted teeth, divided into 2 experimental groups, were used in the research. In the first group, the tooth cavity was treated mechanically and medically without ultrasound use. In the second group, the tooth cavity was treated mechanically and medically with ultrasound.

The carious cavity and cavity of the tooth were prepared by an air-turbine handpiece and diamond burs. Then, the walls and the bottom of the tooth cavity were treated with the 3\% solution of sodium hypochlorite or $3 \%$ gel "Belodez" (VladMiVa). In the second group, $3 \%$ solution of sodium hypochlorite injected into the tooth cavity was additionally activated by ultrasound for 60 seconds without touching the walls and bottom of the tooth cavity. The result was assessed visually.

The formation of bubbles and turbidity of the solution, which is the indicator of the washing out of contaminants from the tooth cavity, was observed during the ultrasonic treatment of the tooth cavity.

Thus, ultrasonic treatment improves significantly the quality of cleaning of the walls and bottom of the tooth cavity (Fig. 1, Fig. 2).
When talking about passive ultrasonic irrigation of the root canals, it is worth mentioning that the combination of ultrasound and irrigation solution facilitates the removal of the smear layer, causes the decrease in microorganisms, and improves the cleaning of the areas inaccessible to the instruments (isthmus between channels, lateral tubules) $[7,18]$.

The process of passive ultrasonic irrigation involves 3 phenomena. The first one is the effect of cavitation, that is the process of formation of bubbles that cause the effective washing out of minute contaminants and destruction of molecules of chemical substances and membranes of microbial cells [6]. The second one is the microstreaming (microflow of liquid) that is the process of stable always unidirectional fluid circulation near a small vibrating agent. And finally, apparition of acoustic swirling effects around the file, which contributes to the removal of contaminants, has also an important role $[2,3,5,16]$.

There are certain rules for passive ultrasonic irrigation of the root canals, such as the preliminary injection of the irrigation solution into the root canal and the free placement of the ultrasound file into the area in root canal without contact to its walls $[4,19]$.

30 extracted teeth, divided into 3 experimental groups were used in our study to demonstrate the efficiency of passive ultrasonic irrigation. In the first control group, irrigation of the root canals was carried out with a $3 \%$ solution of sodium hypochlorite. In the second group, sodium hypochlorite solution was activated with ultrasound. In the 


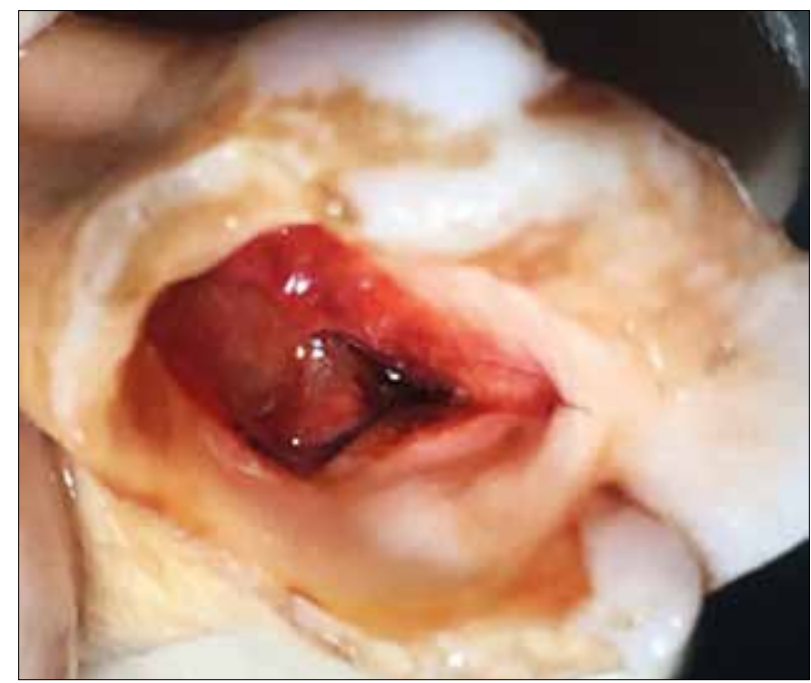

Fig. 2. The 16th tooth cavity after ultrasound treatment

third group, sodium hypochlorite solution was activated with sound.

Root canals preparation was carried out mechanically with rotating nickel-titanium tools ProTaper, then medicinally with $3 \%$ sodium hypochlorite solution. In the second group, the ultrasonic treatment with an endochac and ultrasound file No.15 (ISO) was conducted 3 times for 20 seconds. In the third experimental group, sound activation of the irrigation solution with Sonic Air was conducted 3 times for 20 seconds. Then the tooth slices that were studied with scanning electron microscopy were obtained.

\section{RESULTS AND DISCUSSION}

Scanning electron microscopy of the removed tooth slices of the first experimental group showed a large amount of dentine sawdust that indicates a high level of root canal contamination. The presence of open dentinal tubules was minimal almost none (Fig. 3, Fig. 4). Another situation can be seen in the electron microscopy of the tooth slices of the second group, which were treated with passive ultrasonic irrigation. A large number of open dentinal tubules was obvious (Fig. 5, Fig. 6).

We can conclude that passive ultrasonic irrigation contributed to the maximum removal of dentine sawdust, and to the opening of dentinal tubules on the inner wall of the root canal.

Electron microscopy of the second and third experimental groups showed a large number of open dentinal tubules with a minimal amount of dentin sawdust (Fig. 5, Fig. 6, Fig. 7).
Thus, we can say that the quality of root canal cleaning in the control group was significantly worse than in the second and third groups. When comparing the quality of root canal cleaning with sodium hypochlorite solution, activated by ultrasound (in the second group) and sound (in the third group), no significant difference was found.

Ultrasound is also used often to extract anchor posts. Nevertheless it is important to avoid overheating of surrounding tissues due to the high power of ultrasound required to remove metal structures $[14,15]$. Therefore, it is necessary to know and follow the general principles of ultrasonic use of attachments while removing posts, such as to operate intermittently at maximum power with water and air cooling and with irrigation [16]. The ultrasonic tip should be applied counterclockwise around the post as if it was unscrewed, or tightly to the vertical axis of the pin, which will be a conditional extension of the ultrasonic tip. Thus, the ultrasound energy is transmitted through the post to the cement, breaking it and pushing the post outside the tooth [13].

The use of ultrasound also facilitates the extraction of silver posts. For example, in the clinical case № 1, a patient P., 52 years old, was being prepeared for dental prosthetics. In the X-ray of the 22 nd tooth a silver pin was determined (Fig. 8). The extraction of the pin from the root canal of the 22nd tooth was carried out with ultrasound use.

In clinical case № 2, 43 year old patient $\mathrm{R}$. had a fiberglass post in the root canal of the 


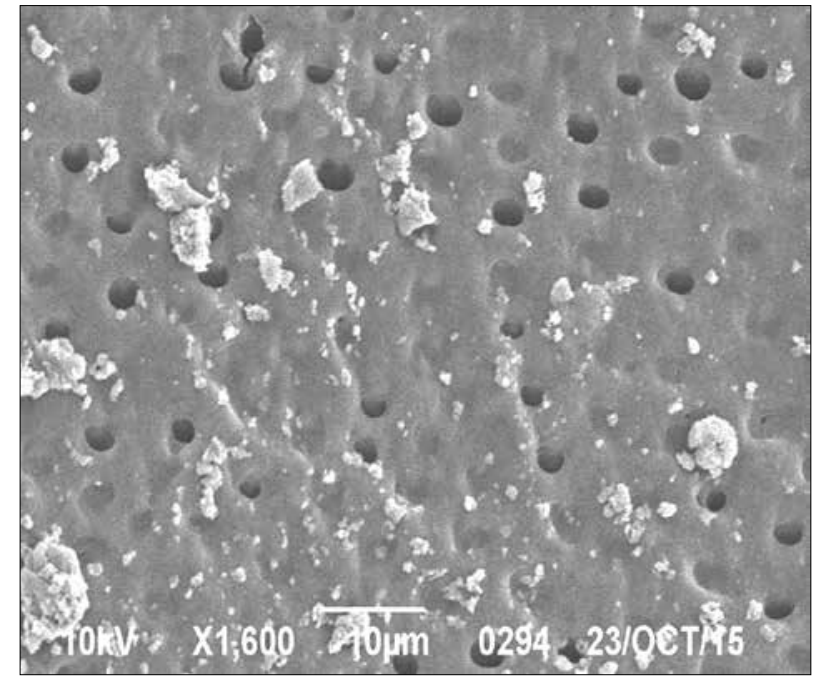

Fig. 4. Scanning electron microscopy of a slice of the extracted tooth of the I group (sodium hypochlorite) in increase $x 1600$

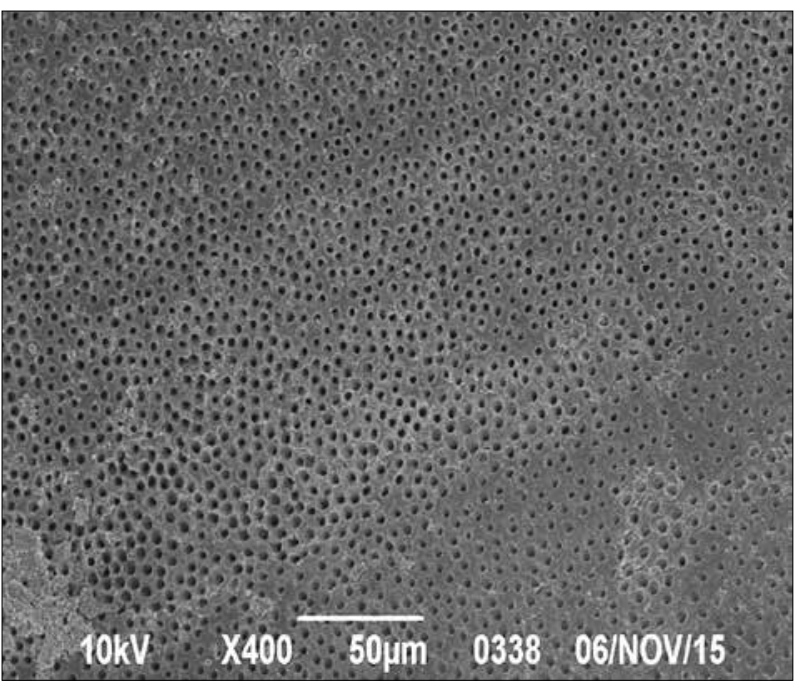

Fig. 5. Scanning electron microscopy of a slice of the extracted tooth of the II group (sodium hypochlorite + ultrasound) in increase $x 400$

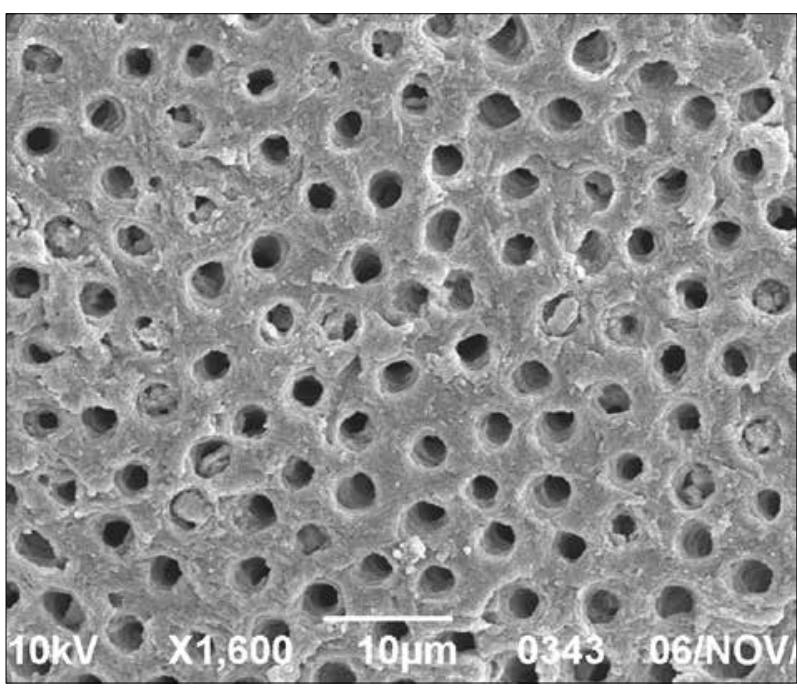

Fig. 7. Scanning electron microscopy of a slice of the extracted tooth of the III group (sodium hypochlorite + sound) in increase x1600

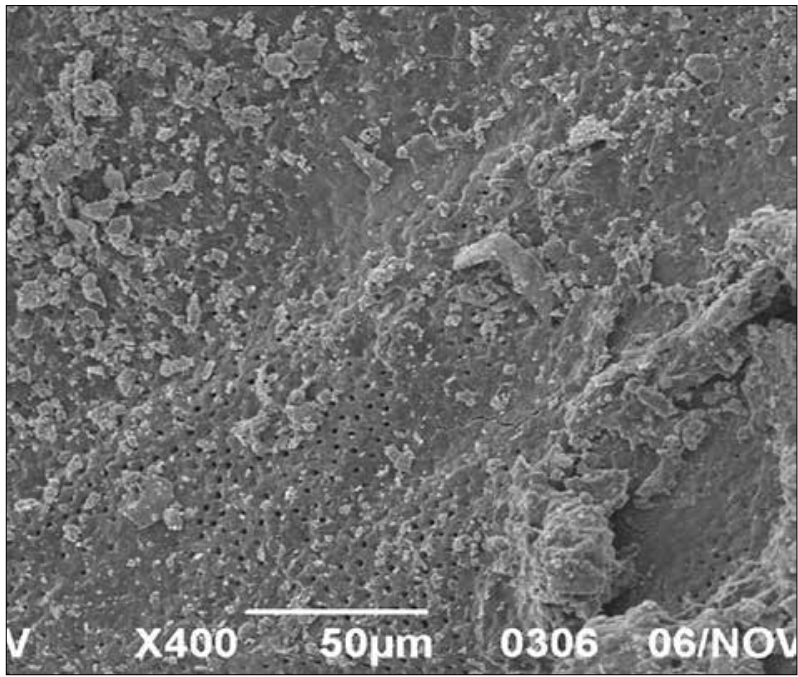

Fig. 3. Scanning electron microscopy of a slice of the extracted tooth of the I group (sodium hypochlorite) in increase $\times 400$

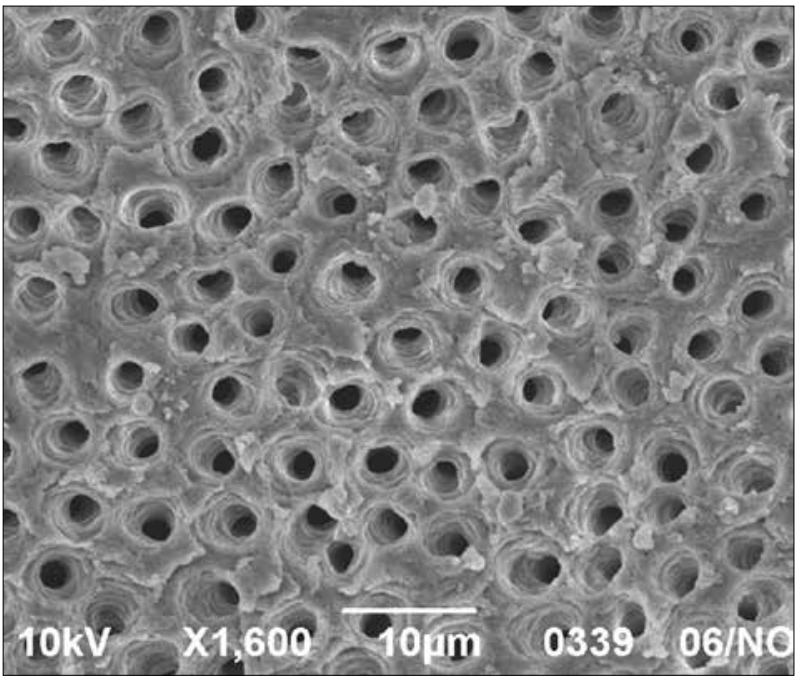

Fig. 6. Scanning electron microscopy of a slice of the extracted tooth of the II group (sodium hypochlorite + ultrasound) in increase x1600

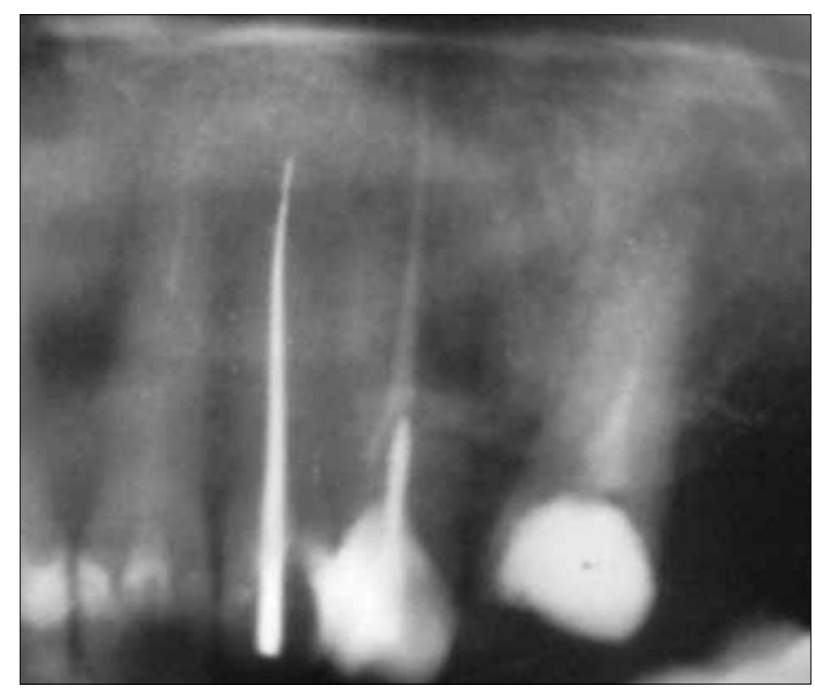

Fig. 8. Clinical case №1. X-ray of the 22nd tooth before the retreatment 


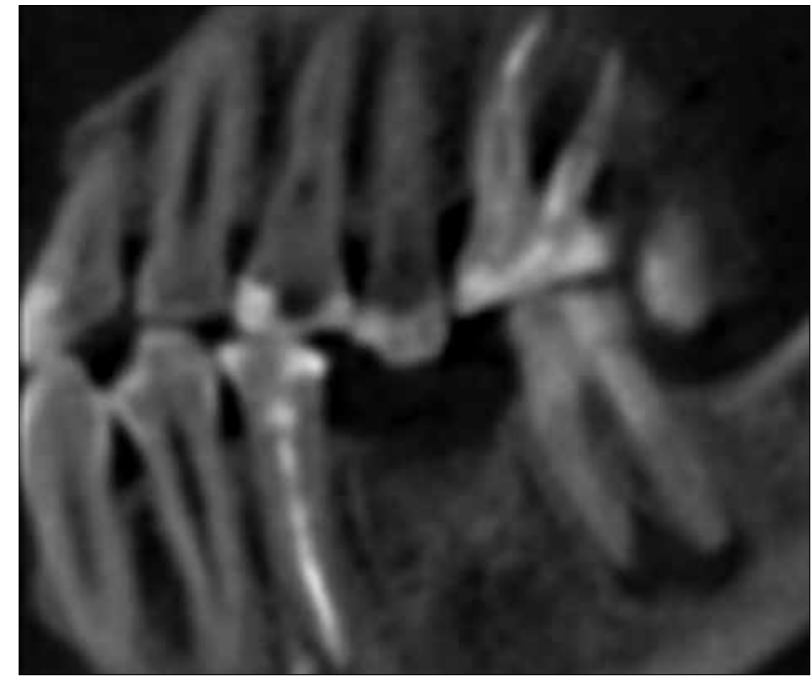

Fig. 9. Clinical case №2. The 35th tooth with fiber glass post on CBCT tomography

35th tooth. The post was extracted with ultrasonic tip E7 (Fig. 9). Check-up X-ray of the 35 th tooth after removal of the fiberglass post showed that the root canal can be crossed to the apex (Fig. 10).

In the fourth part of our research, we would like to pay attention to the procedure of extracting broken tool parts from the root canal as to one of the most difficult and time-consuming manipulations in endodontics. Removing fragment of instruments from the root canal is often accompanied by a high risk of creating a perforation of the root canal wall or transporting the fragment distally to the

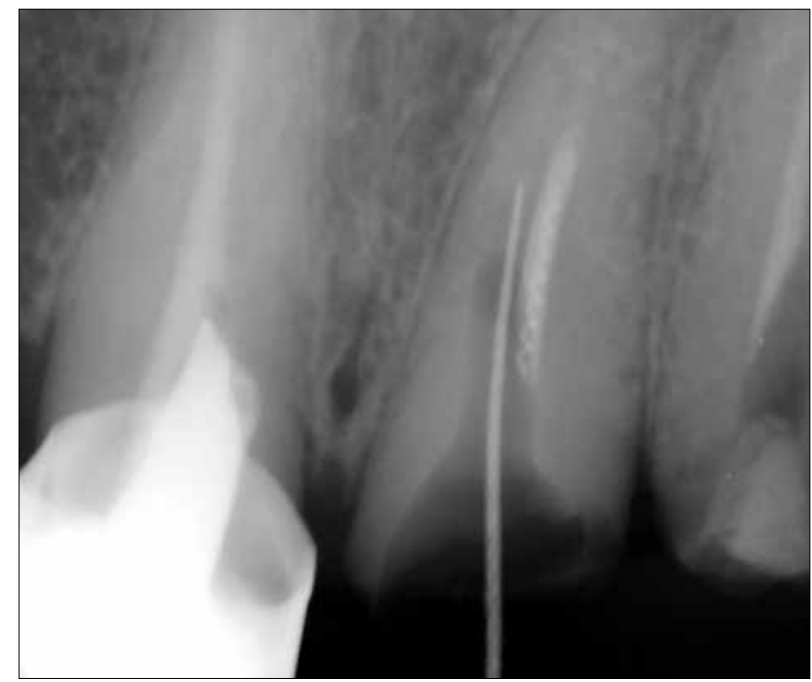

Fig. 11. Clinical case №3. Check-up X-ray of the 21st tooth with a deviation from the natural course of the root canal and broken part of the canal filling instrument

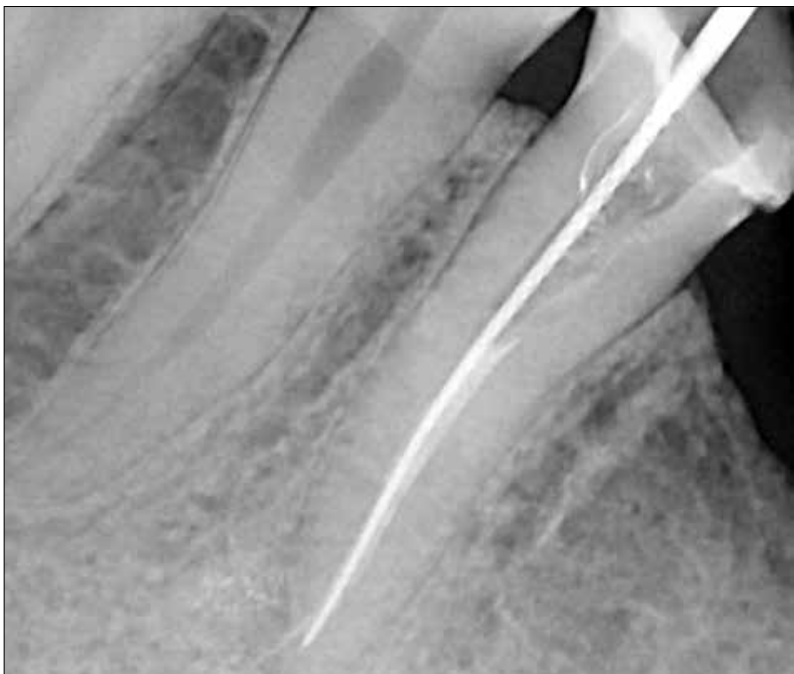

Fig. 10. Clinical case №2. Check-up X-ray of the 35th tooth after the fiber glass post removal

apex. The application of ultrasound during this manipulation allows us to preserve as much of dentin of the tooth root as possible $[20,21,23]$.

The manipulation of broken instruments removal using ultrasound should include the following main steps:

1. Diagnostic CBCT tomography or intraoral X-ray.

2. Creating the direct access to the fragment and its visualization.

3. Weakening of the fragment position in the root canal.

4. Removal of the broken tool fragment.

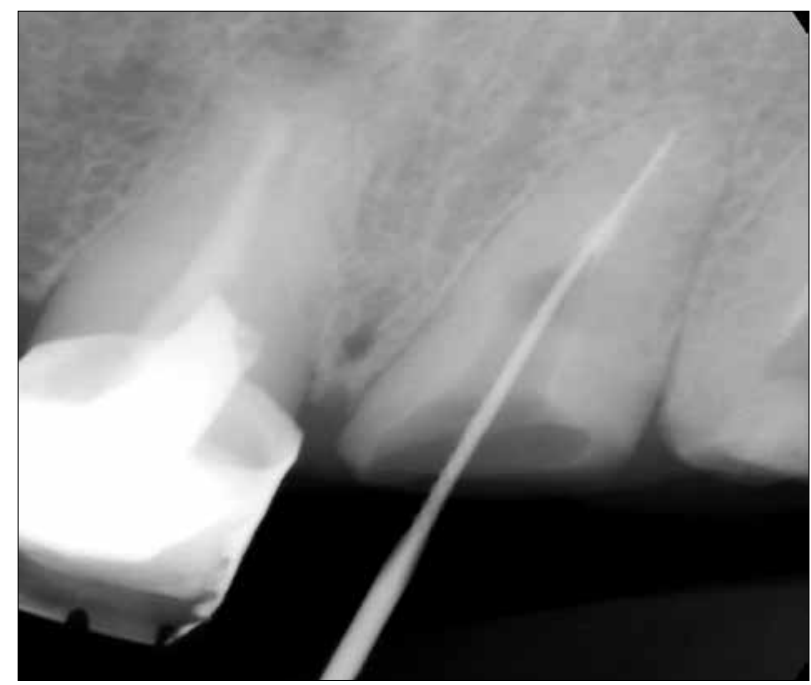

Fig. 12. Clinical case №3. X-ray of the 21 st tooth with the file inducted till the apex 
The weakening of the fragment position in the root canal is carried out with thin endodontic tips, with which the dentin is removed from around the fragment of the instrument. Thus, a groove is created around the fragment, into which the ultrasonic tip will be placed for further manipulations [22].

It is worth mentioning that before extraction of broken tool fragments being started, it is necessary to make a proper assessment of the clinical cases and make the best decision whether to remove the fragment or refuse to extract it, because an attempt of fragment extraction could result in the loss of a large amount of dentin, and therefore the tooth will no longer be able to bear the occlusal load and will be subject to extraction.

In clinical case №3, broken part of the canal filling instrument in the middle part of the root canal and a deviation from the natural course of the root canal can be seen in the $\mathrm{X}$-ray of the 21 st tooth of 56 year old patient K (Fig. 11). After removal of the broken part of the canal filling instrument with ultrasound, a revision of the root canal was conducted (Fig. 12).

It is also necessary to make an emphasize on the possibility of the negative impact of ultrasound during the extraction of broken instrument parts from the root canal, that is to re-fragment the broken part of the tool. The smaller and the more apical the fragment is, the harder it is to extract. Incorrect application of the ultrasonic tip increases the possibility of displacement of the broken file from the canal beyond the apex in the periodontal tissues. Moreover, continuous application of ultrasound is accompanied by heating of tissues, so it is very important to use water and air cooling while working with ultrasound $[15,17]$.

\section{- CONCLUSION}

According to the results of our study, we can make the following conclusions:

1. Application of ultrasound increases the efficiency of dental cavity cleaning.

2 . The sound and ultrasound irrigation leads to significant improvement in the quality of root canal cleaning.

3. Application of ultrasound facilitates process of fiber glass removal, anchor and silver posts from the root canal with the maximal preservation of intact dental tissue.

4. In many clinical cases, ultrasound is a method to be used for the removal of broken instrument from the root canal.

\section{- References}

1. Ali Nassey. Novye tekhnologii v endodontii. [New technologies in endodontics]. Endodontiya today. - Endodontics today. 2008, no. 1, pp. 14-16.

2. Barer G.M., Ovchinnikova I.A. Apparat Piezon - Master 400 ot Shveytsarskoy firmy EMS. [Piezon - Master 400 from the Swiss company EMS]. Klinicheskaya stomatologiya. - Clinical dentistry. 1998, no. 3, pp. 58-61.

3. Ber R., Baumann M.A., Kim S. Endodontologiya. [Endodontology] Moscow: MEDpress-inform, 2010. 366 p.

4. Gatina E.N., Egorova G.R., Fazylova Yu.V. Sovremennye vozmozhnosti irrigatsii kornevykh kanalov. [Modern possibilities of root canals irrigation]. Molodoy uchenyy. - Young Scientist. 2015, no. 11, pp. 631-635.

5. Zender M., Frank Paque F. Dezinfektsiya sistemy kornevykh kanalov vo vremya povtornogo endodonticheskogo lecheniya.

[Desinfection of system of root canals during repeated endodontic treatment]. Endodontija. - Endodontology. 2015, no. 1-2, Vol. 7, pp. 7-21.

6. Il'gamov M.A., Smorodov E.A., Galiakhmetov R.N. Fizika i khimiya kavitatsii. [Physics and chemistry of cavitation]. Nauka. Science. 2008, no. 3, pp. 228.

7. Kantatore D. Irrigatsiya kornevykh kanalov i ee rol' v ochistke i sterilizatsii sistem kornevykh kanalov. [Irrigation of root canals and its role in cleaning and sterilization of root canal systems]. Novosti Dentsply. - Dentsply News. 2004, no. 10.

8. Lamli F., Adams N., Tomson F. Prakticheskaya klinicheskaya endodontiya. [Clinical Endodontics] Moscow: MEDpress-inform, 2007, pp. 73-89.

9. Rabinovich M., Kornetova I. V. Opyt primeneniya vysokikh tekhnologiy v endodontii. [Experience in using of high technology in endodontics]. Endodontiya today. - Endodontics today. 2013, no. 2, pp. 12-17.

10. Udod A.A., Fomina T.V. Ul'trazvuk v endodontii: vozmozhnosti i perspektivy. [Ultrasound in Endodontics: Opportunities and Perspectives]. Mir meditsiny i biologii. - The world of medicine and biology. 2013, no. 4-1(41), Vol. 9, pp.117-119.

11. Khyul'smann M., Shefer E. Problemy endodontii. Profilaktika, vyyavlenie i ustranenie. [Problems of endodontics. Prevention, detection and elimination] - Moscow: Azbuka, 2009, pp. 435-455.

12. Shpak T.A., Kamenskikh M. Klinicheskie osobennosti primeneniya ul'trazvuka na etapakh endodonticheskogo lecheniya. [Clinical features of application of ultrasound at stages of endodontic treatment]. Maestro stomatologii. - Maestro of dentistry. 2015, no. 1 (57), pp. 29-31.

13. Buoncristiani J., Seto G.B., Caputo A.A. Evaluation of ultrasonic and sonic instruments for intraradicular post removal. Journal of Endodontics, 1994, no. 20, pp. 486-489.

14. Dominici J.T., Clark S., Scheetz J. Analysis of heat generation using ultrasonic vibration for post removal. Journal of Endodontics, 2005, no. 31, pp. 301-303. 
15. Gluskin A.H., Ruddle C.J., Zinman E.J. Thermal injury through intraradicular heat transfer using ultrasonic devices: precautions and practical preventive strategies. The Journal of the American Dental Association, 2005, no. 136, pp. $1286-1293$.

16. Gorni F. The Use of Ultrasound in Endodontics. Roots, 2006, vol. 1, no. 1, pp. 58-65.

17. Hashem A.A. Ultrasonic vibration: temperature rise on external root surface during broken instrument removal. Journal of Endodontics, 2007, no. 33, pp. 1070-1073.

18. Martin H. Ultrasonic disinfection of root canal. Oral Surgery, 1976, no. 42, pp. 92-99.

19. Martin H., Cunningham W. Endosonic endodontics the ultrasound synergistic system. International Dental Journal, 1984, no. 34 (3), pp. 198-203.

20. Nagai O., Tagi N., Kayaba Y., Kodama S. Ultrasonic removal of broken instruments in root canals. International Endodontic Journal, 1986, no. 19, pp. 298-304.

21. Ruddle C.J. Removal of broken instruments. Endodontic Practice, 2003, no. 6, pp. 13-19.

22. Terauchi Y. Separated file removal. Dentistry Today, 2012.

23. Ward J.R., Parashos P, Messer H.H. Evaluation of an ultrasonic technique to remove fractured rotary nickel-titanium instruments from root canals: an experimental study. Journal of Endodontics, 2003, no. 29, pp. 756-763.

24. Wilcox L.R. Endodontic retreatment: ultrasonic and chloroform as final step in reinstrumentation. Journal of Endodontics, 1989, no. 15 (3), p. 125.

25. Yahya A.S., ELDeeb M.E. Effect of sonic versus ultrasonic instrumentation on canal preparation. Journal of Endodontics, 1989 , no. 15 , p. $235-239$.

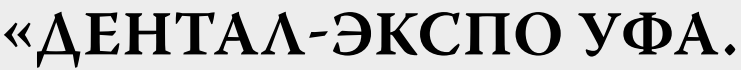 СТОМАТОАОГИЯ УРААА 2017» \\ 17 - 19 октября Уфа, Россия -}

пройдет 18-я специализированная выставка «Аентал-Экспо Уфа. Стоматомогия Урама 2017».

\section{Место проведения:}

Уфа, ум. Мендемеева, 158, ВАНХ-ЭКСПО

Phone: +7 (499) 707-23-07

Email:info@dental-expo.com

\section{«АНТИМА. АЕНТА $\Lambda$-ЭКСПО НОВОСИБИРСК - 2017» 18 - 20 октября Новосибирск, Россия - пройдет выставка «Аентима Сибирь» поА новым названием - «Аентима. Аентац-Экспо Новосибирск».}

\section{Место провеАения:}

Новосибирск, ул. Станционная, 104 (МВК «Новосибирск Экспоцентр»)

Phone: +7 (383) 363-00-63

Email: dentima@sibfair.ru 